\title{
Rapid hydrogen generation from aluminum-water system by adjusting water ratio to various aluminum/aluminum hydroxide
}

\author{
Yu-Kuang Chen • Hsin-Te Teng • To-Ying Lee • \\ Hong-Wen Wang
}

Received: 21 August 2013/Accepted: 28 November 2013/Published online: 4 April 2014

(C) The Author(s) 2014. This article is published with open access at Springerlink.com

\begin{abstract}
The effect of $\mathrm{Al}(\mathrm{OH})_{3}$ on the hydrogen generation from $\mathrm{Al} /$ water system is evaluated. Four synthesized and one commercial $\mathrm{Al}(\mathrm{OH})_{3}$ powders are employed to investigate their assistance to the hydrogen generation from $\mathrm{Al} /$ water system at room temperature. It was found that the $\mathrm{Al}(\mathrm{OH})_{3}$ product derived from $\mathrm{Al}(\mathrm{NO})_{3}$ precursor exhibits the best catalytic effect and exerts the highest hydrogen generation rate. $100 \%$ yield of hydrogen $(1,360 \mathrm{ml} / \mathrm{g} \mathrm{Al}$ at $25^{\circ} \mathrm{C}$ ) can be achieved within $6 \mathrm{~min}$ at a proper $\mathrm{Al}: \mathrm{Al}(\mathrm{OH})_{3}: \mathrm{H}_{2} \mathrm{O}$ weight ratio $(3: 15: 50)$. That is, by adjusting $\mathrm{Al}: \mathrm{Al}(\mathrm{OH})_{3}: \mathrm{H}_{2} \mathrm{O}$ ratio, the highest hydrogen generation rate ever reported so far, without using any alloying elements or corrosive additives, can be achieved.
\end{abstract}

Keywords Water Aluminum hydroxide $\cdot$ Hydrogen generation

\section{Introduction}

Hydrogen is an ideal energy source due to its harmless effect to environment [1]. However, the storage and transportation of hydrogen gas is still challenging nowadays. One solution to this issue is to development a use-ondemand hydrogen source. Aluminum, abundant in earth, has low density, high capacity and excellent activity to water and is a superior material for hydrogen generation

5th International Congress on Energy and Environmental Engineering and Management (CIIEM).

Y.-K. Chen · H.-T. Teng · T.-Y. Lee · H.-W. Wang ( $\varangle)$ Department of Chemistry, Master Program of Nanotechnology, Center for Nanotechnology, Chung-Yuan Christian University, Chungli 320, Taiwan

e-mail: hongwen@cycu.edu.tw
[2]. In addition, the product of $\mathrm{Al} /$ water reaction is $\mathrm{Al}(\mathrm{OH})_{3}$ or $\mathrm{AlOOH}$, which is easily recycled to produce $\mathrm{Al}$ by Halle-Heroult process [3]. However, the high activity of Al to water is prohibited by a thin layer of aluminum oxide on its surface. The generation of hydrogen can be achieved using highly corrosive basic solution such as sodium hydroxide [2]. In recent reports [4, 5], sodium stannatedoped sodium hydroxide solution effectively promoted hydrogen generation from the $\mathrm{Al} / \mathrm{H}_{2} \mathrm{O}$ system by weakening the oxide layer using sodium hydroxide and oxidizing Al by reducing the $\mathrm{Sn}(\mathrm{OH})_{6}^{-2}$ ions. The usage of sodium hydroxide could be reduced. However, the continuous and subsequent hydrogen generation reactions require more sodium stannate, and the accumulation of $\mathrm{Sn}$ metal waste could also interfere with the practical application of this system. A fascinating report by Rosenband [6] showed that $6-\mu \mathrm{m}$-sized $\mathrm{Al}$ in water could yield $100 \%$ hydrogen in less than $5 \mathrm{~min}$ by their in-house activated treatment of $\mathrm{Al}$ powders. Al-Ga alloys [7, 8], $\mathrm{KCl} / \mathrm{NaCl}$ [9] or metallic oxide modifiers [10-15] are also employed to enhance the generation of hydrogen. However, these methods, accompanied with potential pollution, high cost, and additional energy supply, are not very attractive. Deng et al. [12-15] reported that $\gamma-\mathrm{Al}_{2} \mathrm{O}_{3}$ is an excellent modifier of aluminum power for hydrogen generation. In their study, a powder mixture of $\mathrm{Al}$ and $\mathrm{Al}(\mathrm{OH})_{3}$ was used to form porous $\mathrm{Al} / \gamma$ $\mathrm{Al}_{2} \mathrm{O}_{3}$ composite after sintering $[12,13]$. In our previous study $[16,17], \mathrm{Al}(\mathrm{OH})_{3}$ was proved to be very effective to promote hydrogen generation from $\mathrm{Al} /$ water system when it is small in size and of low crystallinity. In the present study, to better understand the effectiveness of $\mathrm{Al}(\mathrm{OH})_{3}$ powders on the reaction of $\mathrm{Al}$ and water, five different sources of $\mathrm{Al}(\mathrm{OH})_{3}$ were evaluated. An optimum condition is obtained, which produces $100 \%$ yield hydrogen $\left(1,360 \mathrm{ml} / \mathrm{g} \mathrm{Al}\right.$ at $\left.25^{\circ} \mathrm{C}\right)$ from neutral water within $6 \mathrm{~min}$ 
using effective $\mathrm{Al}(\mathrm{OH})_{3}$ powders and taking advantages of exothermic heat from the $\mathrm{Al}-$ water reaction.

\section{Experimental procedures}

\section{Chemicals}

Aluminum nitrate nonahydrate $\left(\mathrm{Al}\left(\mathrm{NO}_{3}\right)_{3} \cdot 9 \mathrm{H}_{2} \mathrm{O}, \geq 98.0 \%\right.$, SHOWA), aluminum chloride nonahydrate $\left(\mathrm{AlCl}_{3} \cdot 6 \mathrm{H}_{2} \mathrm{O}\right.$, $\geq 97.0 \%$, SHOWA), sodium aluminate $\left(\mathrm{NaAlO}_{2}\right.$, $\geq 99.0 \%$, SHOWA), and sodium hydroxide $(\mathrm{NaOH}$, $\geq 97 \%$, Sigma-Aldrich) were purchased and used for the preparation of aluminum hydroxide. Commercial $\mathrm{Al}(\mathrm{OH})_{3}$ $(0.5 \mu \mathrm{m}, \geq 98 \%$, NanoAmor) was also purchased and used directly. Reaction product $\mathrm{Al}(\mathrm{OH})_{3}$ from the reaction of $\mathrm{Al}$ and water counts the fifth source of aluminum hydroxide. These five aluminum hydroxides were evaluated for their effects on the reaction of $\mathrm{Al} / \mathrm{H}_{2} \mathrm{O}$ system. Deionized (D.I.) water $\quad(\mathrm{pH}=\sim 7.0$, resistivity $>18 \mathrm{M} \Omega \mathrm{cm}$ ), and metallic Al powders (325 mesh, purity $\geq 99.5 \%$, APS 7-15 $\mu \mathrm{m}$, CAS \# 7429-90-5, Alfa Aesar) were used for all experiments of hydrogen generation in this study.

Preparation of aluminum hydroxide

Aluminum hydroxide derived from $\mathrm{AlCl}_{3}, \mathrm{Al}\left(\mathrm{NO}_{3}\right)_{3}$ and $\mathrm{NaAlO}_{2}$ are obtained by following procedures according the well-known chemical reactions as follows:

$$
\begin{aligned}
& \mathrm{AlCl}_{3}+3 \mathrm{NaOH} \rightarrow 3 \mathrm{NaCl}+\mathrm{Al}(\mathrm{OH})_{3} \\
& \mathrm{Al}\left(\mathrm{NO}_{3}\right)_{3}+3 \mathrm{NaOH} \rightarrow 3 \mathrm{Na}\left(\mathrm{NO}_{3}\right)_{3}+\mathrm{Al}(\mathrm{OH})_{3} \\
& \mathrm{AlCl}_{3}+3 \mathrm{NaAlO}_{2}+6 \mathrm{H}_{2} \mathrm{O} \rightarrow 3 \mathrm{NaCl}+4 \mathrm{Al}(\mathrm{OH})_{3}
\end{aligned}
$$

That is, $0.1 \mathrm{M} \mathrm{AlCl}{ }_{3}, \mathrm{Al}\left(\mathrm{NO}_{3}\right)_{3}$, and $0.4 \mathrm{M} \mathrm{NaOH}$, $\mathrm{NaAlO}_{2}$ were first produced in D.I. water. The $\mathrm{NaAlO}_{2}$ aqueous solution was obtained by dissolving $\mathrm{NaAlO}_{2}$ in D.I. water at $50{ }^{\circ} \mathrm{C}$. The $\mathrm{AlCl}_{3}$ aqueous solution was gradually dripped into a $\mathrm{NaOH}$ solution by stirring for $24 \mathrm{~h}$. The white precipitates $\mathrm{Al}(\mathrm{OH})_{3}$ were separated from liquid by centrifugation. After washing twice using $0.01 \mathrm{M}$ $\mathrm{HCl}$ aqueous solution and three times using D.I. water, the precipitates were freeze-dried for use. This $\mathrm{Al}(\mathrm{OH})_{3}$ powder obtained was referred as $\mathrm{Al}(\mathrm{OH})_{3}-\mathrm{AlCl}_{3}$. The $\mathrm{Al}(\mathrm{OH})_{3}$ powders derived from $\mathrm{Al}\left(\mathrm{NO}_{3}\right)_{3}$ and $\mathrm{NaOH}$ solutions follow the same procedure described above. This $\mathrm{Al}(\mathrm{OH})_{3}$ powder obtained was referred to as $\mathrm{Al}(\mathrm{OH})_{3}-\mathrm{Al}\left(\mathrm{NO}_{3}\right)_{3}$. The third $\mathrm{Al}(\mathrm{OH})_{3}$ powder was obtained from the reaction of $\mathrm{AlCl}_{3}$ and $\mathrm{NaAlO}_{2}$ solution, whose fabrication process was the same as that for $\mathrm{Al}(\mathrm{OH})_{3}-\mathrm{AlCl}_{3}$ except the aqueous solution was obtained at $50{ }^{\circ} \mathrm{C}$. The fourth $\mathrm{Al}(\mathrm{OH})_{3}$ powder was obtained by the reaction of metallic $\mathrm{Al}$ powder in D.I. water at $35^{\circ} \mathrm{C}$ [reaction (4)], which took more than $18 \mathrm{~h}$ to complete. This $\mathrm{Al}(\mathrm{OH})_{3}$ powder obtained was referred as $\mathrm{Al}(\mathrm{OH})_{3}-\mathrm{Al}$ reacted.

$2 \mathrm{Al}+6 \mathrm{H}_{2} \mathrm{O} \rightarrow 2 \mathrm{Al}(\mathrm{OH})_{3}+\mathrm{H}_{2}$

The fifth $\mathrm{Al}(\mathrm{OH})_{3}$ powder $(0.5 \mu \mathrm{m}, \geq 98 \%$, NanoAmor $)$ is commercially purchased and used as-received.

\section{Experimental}

One gram of various $\mathrm{Al}(\mathrm{OH})_{3}$ was put into a flask and $200 \mathrm{ml}$ D.I. water was added and shaken for a uniform mixture. One gram of $\mathrm{Al}$ powder was then added into this mixture for reaction. The temperature is kept constant by putting the flask in a circulated water bath $\left(25 \pm 1{ }^{\circ} \mathrm{C}\right)$. The hydrogen generated was measured by a precision gas flow meter connected after passing a condensing cold trap. In order to search an optimum combination of $\mathrm{Al}, \mathrm{Al}(\mathrm{OH})_{3}$ and water for hydrogen generation, the amount of D.I. water was modified to be 200, 100, and $50 \mathrm{ml}$ for the commercial $0.5 \mu \mathrm{m} \mathrm{Al}(\mathrm{OH})_{3}$ powder. The quantity of $\mathrm{Al}(\mathrm{OH})_{3}$ in $200 \mathrm{ml}$ D.I. water was also changed to 3, 5, 8, and $15 \mathrm{~g}$. Finally, the metal $\mathrm{Al}$ powder was ranged from 1 , 2 , and $3 \mathrm{~g}$ in $50 \mathrm{ml}$ D.I. water and $15 \mathrm{~g}$ of $\mathrm{Al}(\mathrm{OH})_{3}$.

\section{Characterizations}

All of the experiments were carried out at room temperature $\left(25 \pm 1{ }^{\circ} \mathrm{C}\right)$ using circulating water bath. The water displacement method was used to measure hydrogen generation using two 2,000-ml cylinder meters (reading data error $\pm 20 \mathrm{ml}$ ) because of the rapid speed of the hydrogen generation. After the reaction was completed, the product powders were characterized with an analytical PW3040/60

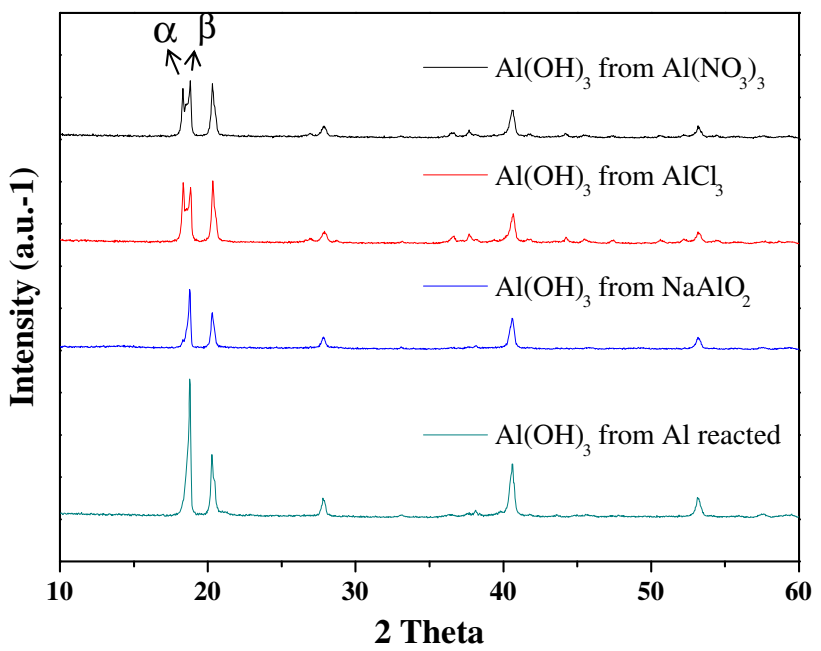

Fig. 1 XRD data for the four synthesized $\mathrm{Al}(\mathrm{OH})_{3}$ powders 
Table 1 Summary of various $\mathrm{Al}(\mathrm{OH})_{3}$ powders used in this study

\begin{tabular}{llllll}
\hline ID & $\mathrm{Al}(\mathrm{OH})_{3}-\mathrm{Al}\left(\mathrm{NO}_{3}\right)_{3}$ & $\mathrm{Al}(\mathrm{OH})_{3}-\mathrm{AlCl}_{3}$ & $\mathrm{Al}(\mathrm{OH})_{3}-\mathrm{NaAlO}_{2}$ & $\begin{array}{l}\text { Commercial as-received } \\
0.5 \mu \mathrm{m}\end{array}$ & $\begin{array}{l}\mathrm{By}-\mathrm{product} \text { after } \\
\mathrm{Al} / \text { water reaction }\end{array}$ \\
\hline Crystalline phase & Gibbsite + Bayerite & Gibbsite + Bayerite & Bayerite & Gibbsite & $\mathrm{Bayerite}$ \\
Assigned name & $\alpha, \beta-\mathrm{Al}(\mathrm{OH})_{3}$ & $\alpha, \beta-\mathrm{Al}(\mathrm{OH})_{3}$ & $\beta-\mathrm{Al}(\mathrm{OH})_{3}$ & $\alpha-\mathrm{Al}(\mathrm{OH})_{3}$ & $\beta-\mathrm{Al}(\mathrm{OH})_{3}$ \\
Particle size $(\mu \mathrm{m})$ & $0.2-0.5$ & $0.2-0.5$ & $0.5-2$ & $0.5-2$ & $1-3$ \\
\hline
\end{tabular}

Fig. 2 FESEM of $\mathrm{Al}(\mathrm{OH})_{3}$ from a $\mathrm{Al}\left(\mathrm{NO}_{3}\right)_{3}, \mathbf{b ~} \mathrm{AlCl}_{3}$, c $\mathrm{NaAlO}_{2}$, d commercial $0.5 \mu \mathrm{m}$, e Al—reacted
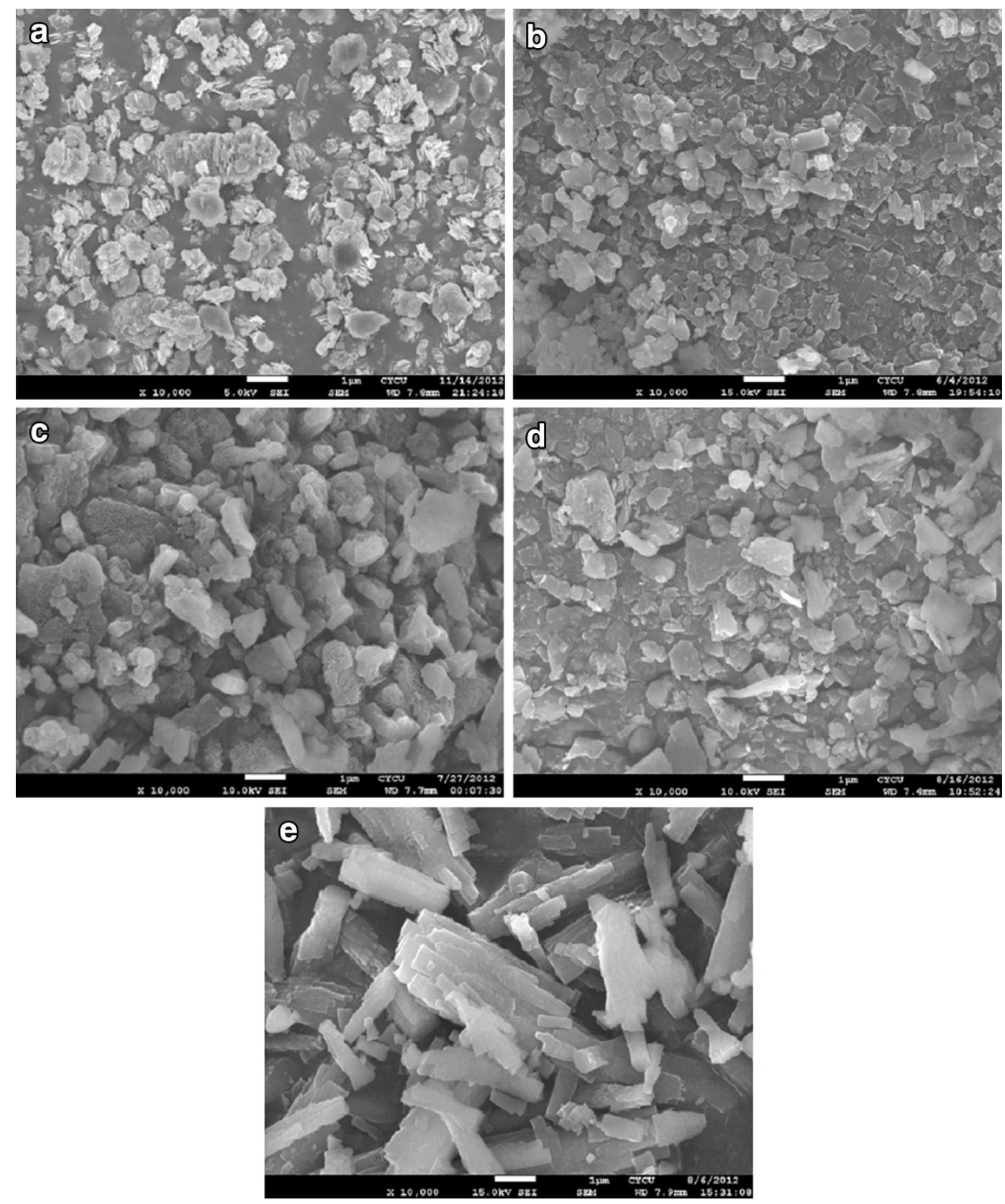

$\mathrm{X}^{\prime}$ Pert Pro X-ray diffractometer using $\mathrm{Cu} \mathrm{K} \alpha$ radiation and an $\mathrm{Ni}$ filter over the angular range of $10^{\circ}-80^{\circ}(2 \theta)$ at a scanning rate of $4^{\circ} \mathrm{min}^{-1}$ and a step size of $0.01^{\circ}$. Fieldemission scanning electron microscopy (FESEM, JEOL JSM 7600F) was employed to characterize the morphology of the powders.

\section{Results and discussion}

Crystal phases and morphologies

Figure 1 shows the XRD results for the four synthesized aluminum hydroxide powders. The two-theta values for 
gibbsite $(\alpha)$ and bayerite $(\beta)$ are $18.392^{\circ}$ and $18.785^{\circ}$, respectively. The $\mathrm{Al}(\mathrm{OH})_{3}$ synthesized from $\mathrm{Al}(\mathrm{NO})_{3}$ and $\mathrm{AlCl}_{3}$ exhibits two mixed phases, i.e. $\alpha$ (gibbsite) and $\beta$ (bayerite), while those obtained from $\mathrm{NaAlO}_{2}$ and $\mathrm{Al} /$ water reaction are only of $\beta$ phase. Gibbsite $(\alpha)$ and bayerite $(\beta)$ differ in the way that the double layers of coordinated $\mathrm{OH}^{-}$ and $\mathrm{Al}^{+3}$ are stacked to form the three-dimensional crystal units [18]. The commercial $\mathrm{Al}(\mathrm{OH})_{3}$ is purely gibbsite (not shown). Table 1 summarizes the characteristic data of all $\mathrm{Al}(\mathrm{OH})_{3}$ used in this study. Figure 2 shows the FESEM images of all $\mathrm{Al}(\mathrm{OH})_{3}$ powders. Powders obtained from $\mathrm{Al}\left(\mathrm{NO}_{3}\right)_{3}$ exhibit smaller crystal sizes with hexagonal thin plates randomly stacking together, while those from $\mathrm{AlCl}_{3}$, $\mathrm{NaAlO}_{2}$ and $\mathrm{Al} /$ water reaction are more bar or barrel-like morphology.

\section{Hydrogen generation}

Figure 3 shows the hydrogen generation from $1 \mathrm{~g} \mathrm{Al}$ in $200 \mathrm{ml}$ D.I. water with $1 \mathrm{~g}$ various catalysts, i.e. five different $\mathrm{Al}(\mathrm{OH})_{3}$ and one $\gamma-\mathrm{Al}_{2} \mathrm{O}_{3}$. The yield "100\%" means the theoretical value of $1,360 \mathrm{ml}$ hydrogen generated per gram $\mathrm{Al}$ metal in water. The performance of $\mathrm{Al}(\mathrm{OH})_{3}$ obtained from $\mathrm{Al}(\mathrm{NO})_{3}$ precursor stands out among all aluminum hydroxides. The reason for this difference will be discussed later. Figure 4 shows the effect of various amounts of commercial $0.5 \mu \mathrm{m} \mathrm{Al}(\mathrm{OH})_{3}$ on the hydrogen generation in $1 \mathrm{~g} \mathrm{Al} / 50 \mathrm{ml}$ D.I. water system. It is clear that higher amount of $\mathrm{Al}(\mathrm{OH})_{3}$ promotes the reaction of $\mathrm{Al}$ and water. We noticed that the exothermic reaction of $\mathrm{Al} /$ water reaction may also assist the hydrogen generation. Previous report [13] also indicated that higher temperature assisted hydrogen generation significantly. In the experiment in Fig. 4, temperature of the reacting flask

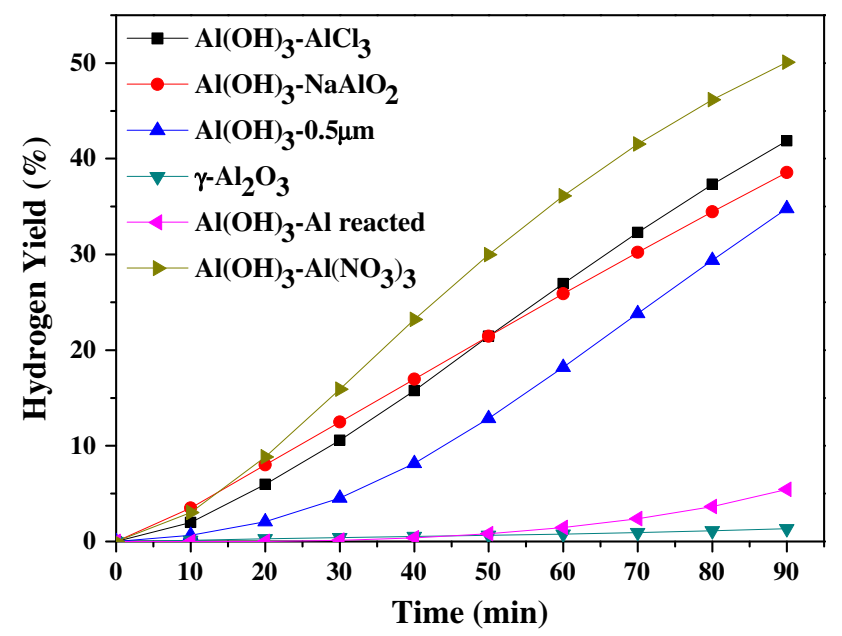

Fig. 3 Hydrogen generation from $1 \mathrm{~g} \mathrm{Al}$ in $200 \mathrm{ml}$ D.I. water with various $1 \mathrm{~g} \mathrm{Al}(\mathrm{OH})_{3}$. Known effective additive, $\gamma-\mathrm{Al}_{2} \mathrm{O}_{3}$, was also evaluated increases due to the smaller amount of water, as shown in Fig. 5, i.e. the exothermic reaction of $\mathrm{Al} /$ water heats up the system. When the weight ratio of $\mathrm{Al}: \mathrm{Al}(\mathrm{OH})_{3}$ : water is $1: 15: 50$, the system temperature could go up to $49^{\circ} \mathrm{C}$. In the meantime, the hydrogen generation yield was also enhanced due to the raised temperature, as shown in Fig. 6. Figure 6 shows the effect of various quantities of commercial $0.5 \mu \mathrm{m} \mathrm{Al}(\mathrm{OH})_{3}$ in 50, 100, and $200 \mathrm{ml}$ D.I. water on the hydrogen generation of $1 \mathrm{~g} \mathrm{Al} /$ water system in $2 \mathrm{~h}$. When water is only $50 \mathrm{ml}$, the exothermic reaction promotes hydrogen yield significantly within 2-h reaction period.

For other synthesized $\mathrm{Al}(\mathrm{OH})_{3}$ powders, the enhancement of hydrogen generation is even more effective, as shown in Fig. 7. Figure 7 demonstrates that the hydrogen yield when the weight ratio of $\mathrm{Al}: \mathrm{Al}(\mathrm{OH})_{3}: \mathrm{H}_{2} \mathrm{O}$ is fixed at

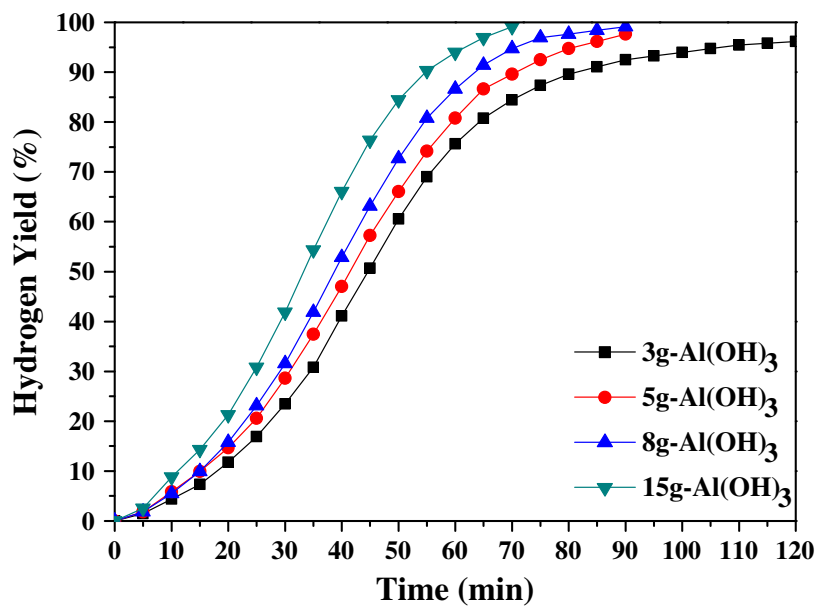

Fig. 4 Effect of commercial $0.5 \mu \mathrm{m} \mathrm{Al}(\mathrm{OH})_{3}$ quantity in $50 \mathrm{ml}$ D.I. water to hydrogen generation of $\mathrm{Al} /$ water system

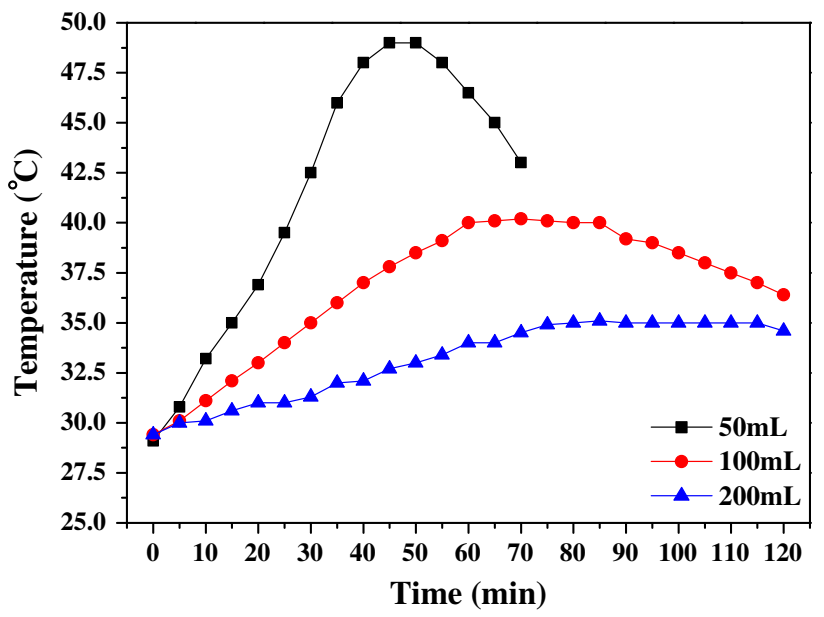

Fig. 5 Temperature rises differently when various amount of water are used for reaction with $1 \mathrm{~g} \mathrm{Al}$ powder 


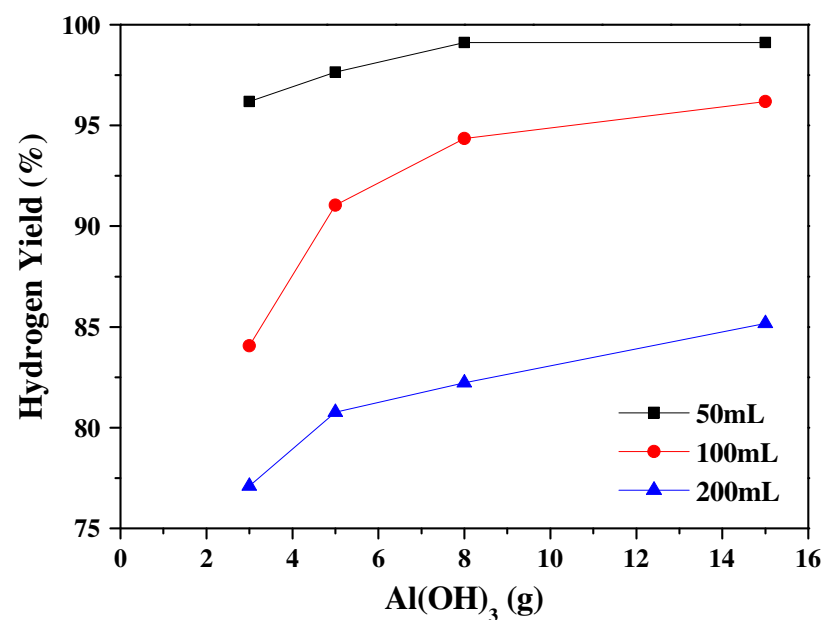

Fig. 6 Effect of quantity of commercial $0.5 \mu \mathrm{m} \mathrm{Al}(\mathrm{OH})_{3}$ in various amount of D.I. water on the hydrogen generation of $1 \mathrm{~g} \mathrm{Al} /$ water system in $2 \mathrm{~h}$

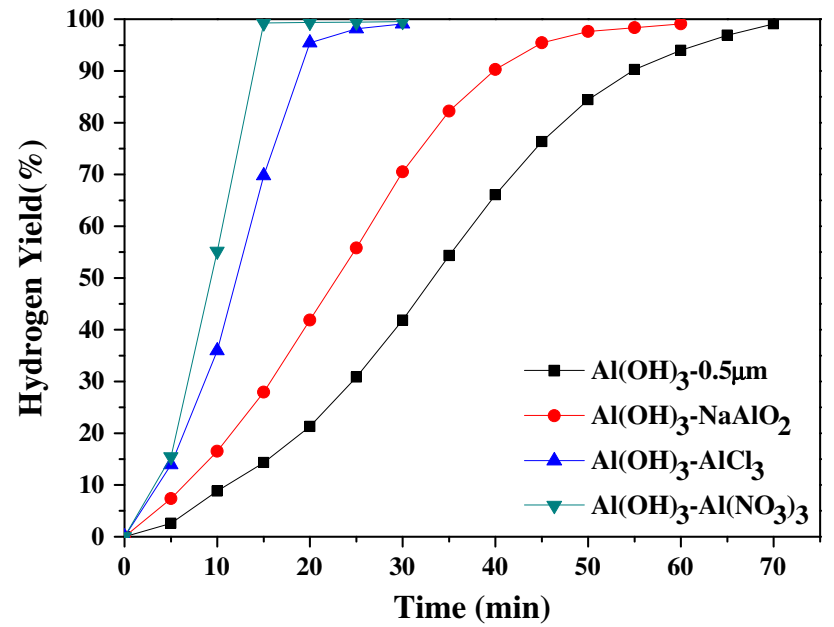

Fig. 7 Effect of various $\mathrm{Al}(\mathrm{OH})_{3}$ in the ratio of 1:15:50 for $\mathrm{Al}: \mathrm{Al}(\mathrm{OH})_{3}: \mathrm{H}_{2} \mathrm{O}$

1:15:50 for various $\mathrm{Al}(\mathrm{OH})_{3} . \mathrm{Al}(\mathrm{OH})_{3}-\mathrm{Al}$ reacted is not presented here due to its slow generation rate, as we have already learned from Fig. 3. It is clear that $\mathrm{Al}(\mathrm{OH})_{3}$ obtained from $\mathrm{Al}\left(\mathrm{NO}_{3}\right)_{3}$ assists $100 \%$ yield of hydrogen from $\mathrm{Al} /$ water reaction in only $15 \mathrm{~min}$. By taking advantage of exothermic reaction of $\mathrm{Al} /$ water system, we can promote $100 \%$ hydrogen yield even faster using higher quantity of metal $\mathrm{Al}$ powders. Figure 8 shows that this expectation is correct. When $3 \mathrm{~g} \mathrm{Al}$ powder is used for reaction in $50 \mathrm{ml}$ water, the exothermic heat is significant and the reaction of hydrogen generation is enhanced. $100 \%$ yield of hydrogen can be released in $6 \mathrm{~min}$ ! The temperature is raised up to $95{ }^{\circ} \mathrm{C}$ in this particular condition, as shown in Fig. 9. The hydrogen generation rate $(\mathrm{ml} /$ min) is also depicted in Fig. 9. The hydrogen generation

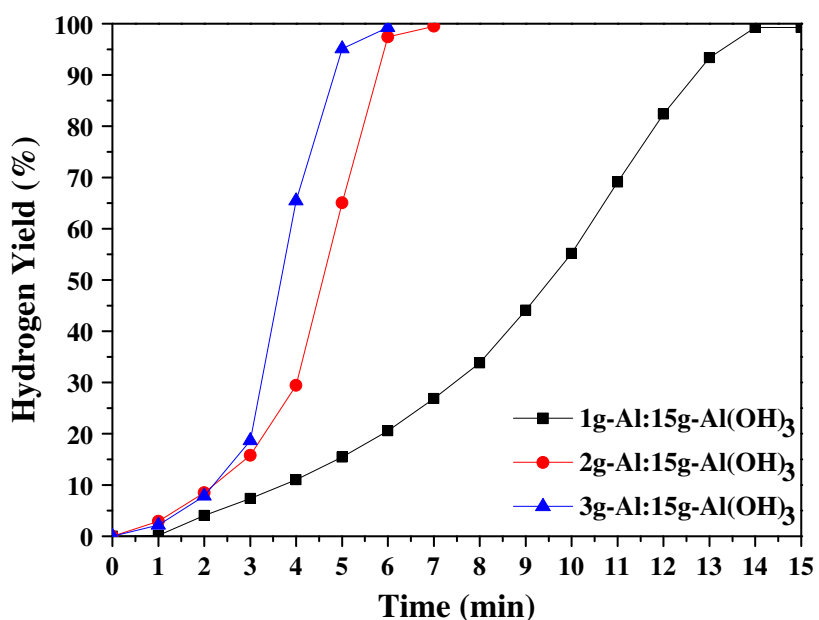

Fig. 8 Effect of increasing amount of $\mathrm{Al}$ on the hydrogen yield from 15:50 for $\mathrm{Al}(\mathrm{OH})_{3}: \mathrm{H}_{2} \mathrm{O}$ system. $\mathrm{Al}(\mathrm{OH})_{3}$ is obtained from $\mathrm{Al}\left(\mathrm{NO}_{3}\right)_{3}$

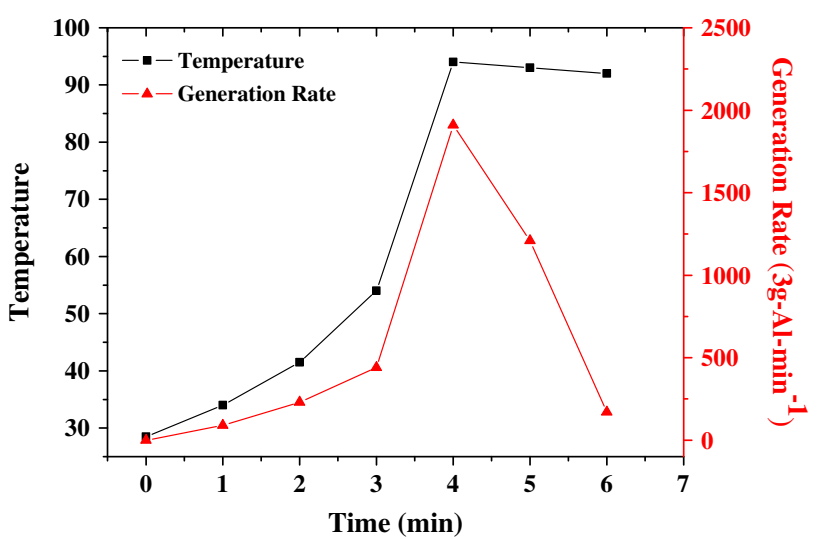

Fig. 9 Temperature profile and hydrogen generation rate per min at the ratio of 3:15:50 for $\mathrm{Al}: \mathrm{Al}(\mathrm{OH})_{3}: \mathrm{H}_{2} \mathrm{O}$ system described in Fig. 8

rate reaches its peak at the fourth minute where the system temperature is also at its peak. The peak rate is as high as $1,920 \mathrm{ml}$ per $3 \mathrm{~g} \mathrm{Al}-\mathrm{min}^{-1}$. After this peak rate, the material consumed up and the hydrogen generation rate declined rapidly.

The reason why $\mathrm{Al}(\mathrm{OH})_{3}$ obtained from $\mathrm{Al}\left(\mathrm{NO}_{3}\right)_{3}$ is so effective to enhance the hydrogen generation from the $\mathrm{Al} /$ water system, while those obtained from other precursors are less effective, is still under investigation. The surface area of $\mathrm{Al}(\mathrm{OH})_{3}$ powders obtained from $\mathrm{Al}\left(\mathrm{NO}_{3}\right)_{3}$ is not particularly high, being only $6 \mathrm{~m}^{2} / \mathrm{g}$. One possible reason is its small size and sharp edge of its randomly stacking hexagonal plate-like crystals. The special morphology of $\mathrm{Al}(\mathrm{OH})_{3}-\mathrm{Al}\left(\mathrm{NO}_{3}\right)_{3}$ is considered to be very effective to react with dense $\mathrm{Al}_{2} \mathrm{O}_{3}$ protecting layer on the metal $\mathrm{Al}$ particles that in turn assists the following reaction we proposed [17]: 


$$
\mathrm{Al}_{2} \mathrm{O}_{3}+\mathrm{Al}(\mathrm{OH})_{3} \rightarrow 3 \mathrm{AlO}(\mathrm{OH})
$$

The boehmite $\mathrm{AlO}(\mathrm{OH})$ could readily react with fresh metal $\mathrm{Al}$ as follows:

$2 \mathrm{Al}+6 \mathrm{AlO}(\mathrm{OH}) \rightarrow 4 \mathrm{Al}_{2} \mathrm{O}_{3}+3 \mathrm{H}_{2}$

By utilizing the in situ self-heating due to the exothermic reaction of $\mathrm{Al} /$ water system, we are able to produce $100 \%$ yield hydrogen within 6 min without using alkaline solution $(\mathrm{pH}<10)$.

\section{Conclusion}

We have demonstrated the novel effect of $\mathrm{Al}(\mathrm{OH})_{3}$ powders on the $\mathrm{Al} / \mathrm{H}_{2} \mathrm{O}$ system for generating hydrogen. When $\mathrm{Al}(\mathrm{OH})_{3}$ powders were obtained from $\mathrm{Al}\left(\mathrm{NO}_{3}\right)_{3}$ precursor, small size and sharp edge of this hexagonal plate-like crystals promote hydrogen generation from $\mathrm{Al}$ /water system significantly. This special morphology of $\mathrm{Al}(\mathrm{OH})_{3}$ is considered to be very effective to react with dense $\mathrm{Al}_{2} \mathrm{O}_{3}$ layer on $\mathrm{Al}$ particles. In addition, an optimum combination of $\mathrm{Al} / \mathrm{Al}(\mathrm{OH})_{3} /$ water $(3: 15: 50)$ for hydrogen generation is revealed. By utilizing the self-heating exothermic reaction from a large quantity of initial $\mathrm{Al}$ powder in a minimum water, the reaction is able to produce high temperature up to $95{ }^{\circ} \mathrm{C}$ and consequently rapid hydrogen generation (100\% yield within 6 min, i.e. $1,360 \mathrm{ml} \mathrm{H}_{2} / \mathrm{g} \mathrm{Al}$ ), making this system an ideal candidate for a hydrogen source in a use-on-demand system.

Acknowledgments We appreciate the financial support from National Science Council, Taiwan, R.O.C. Grant number: NSC992113-M-033-003 -MY3.

Conflict of interest The authors declare that they have no competing interests

Authors' contributions $\mathrm{YK}$ is the main investigator and carried out most of the experiments, HT and TY help the measurements. HW is supervisor. All authors read and approved the final manuscript.

Open Access This article is distributed under the terms of the Creative Commons Attribution License which permits any use, distribution, and reproduction in any medium, provided the original author(s) and the source are credited.

\section{References}

1. Edwards, P.P., Kuznetsov, V.L., David, W.I.F., Brandon, N.P.: Hydrogen and fuel cells : towards a sustainable energy future. Energy Policy 36, 4356-4362 (2008)
2. Belitskus, D.: Reaction of aluminum with sodium hydroxide solution as a source of hydrogen. J. Electrochem. Soc. 117, 1097-1099 (1970)

3. Soler, L., Candela, A.M., Macanas, J., Munoz, M., Casado, J.: Hydrogen generation by aluminum corrosion in seawater promoted by suspensions of aluminum hydroxide. Int. J. Hydrogen Energy 34, 8511-8518 (2009)

4. Soler, L., Candela, A.M., Macanas, J., Munoz, M., Casado, J. Hydrogen generation from water and aluminum promoted by sodium stannate. Int. J. Hydrogen Energy 35, 1038-1048 (2010)

5. Dai, H.B., Ma, G.L., Xia, H.J., Wang, P.: Reaction of aluminum with alkaline sodium stannate solution as a controlled source of hydrogen. Energy Environ. Sci. 4, 2206-2212 (2011)

6. Rosenband, V., Gany, A.: Application of activated aluminum powder for generation of hydrogen from water. Int. J. Hydrogen Energy 35, 10898-10904 (2010)

7. Ziebarth, J.T., Woodall, J.M., Kramer, R.A., Choi, G.: Liquid phase-enabled reaction of $\mathrm{Al}-\mathrm{Ga}$ and $\mathrm{Al}-\mathrm{Ga}-\mathrm{In}-\mathrm{Sn}$ alloys with water. Int. J. Hydrogen Energ 36, 5271-5279 (2011)

8. Wang, W., Zhao, X.M., Chen, D.M., Yang, K.: Insight into the reactivity of Al-Ga-In-Sn alloy with water. Int. J. Hydrogen Energy 37, 2187-2194 (2012)

9. Alinejad, B., Mahmoodi, K.: A novel method for generating hydrogen by hydrolysis of highly activated aluminum nanoparticles in pure water. Int. J. Hydrogen Energy 34, 7934-7938 (2009)

10. Mahmoodi, K., Alinejad, B.: Enhancement of hydrogen generation rate in reaction of aluminum with water. Int. J. Hydrogen Energy 35, 5227-5232 (2010)

11. Parmuzina, A.V., Kravchenko, O.V.: Activation of aluminum metal to evolve hydrogen from water. Int. J. Hydrogen Energy 33, 3073-3076 (2008)

12. Deng, Z.Y., Liu, Y.F., Tanaka, Y., Ye, J.H., Sakka, Y.: Modification of $\mathrm{Al}$ particle surfaces by $\gamma-\mathrm{Al}_{2} \mathrm{O}_{3}$ and Its effect on the corrosion behavior of Al. J. Am. Ceram. Soc. 88(4), 977-979 (2005)

13. Deng, Z.Y., Liu, Y.F., Tanaka, Y., Zhang, H.W., Ye, J.H., Kagwa, Y.: Temperature effect on hydrogen generation by the reaction of $\gamma-\mathrm{Al}_{2} \mathrm{O}_{3}$-modified $\mathrm{Al}$ powder with distilled water. J. Am. Ceram. Soc. 88(10), 2975-2977 (2005)

14. Deng, Z.Y., Ferreira, J.M.F., Tanaka, Y., Ye, J.H.: Physicochemical mechanism for the continuous reaction of $\gamma-\mathrm{Al}_{2} \mathrm{O}_{3}$ modified aluminum powder with water. J. Am. Ceram. Soc. 90(5), 1521-1526 (2007)

15. Deng, Z.Y., Tang, Y.B., Zhu, L.L., Sakka, Y., Ye, J.H.: Effect of different modification agents on hydrogen-generation by the reaction of Al with water. Int. J. Hydrogen Energy 35, 9561-9568 (2010)

16. Wang, H.W., Chung, H.W., Teng, H.T., Guozhong, C.: Generation of hydrogen from aluminum and water-effect of metal oxide nanocrystals and water quality. Int. J. Hydrogen Energy 36, 15136-15144 (2011)

17. Teng, H.T., Lee, T.Y., Chen, Y.K., Wang, H.W., Guozhong, C.: Effect of $\mathrm{Al}(\mathrm{OH})_{3}$ on the hydrogen generation of aluminum-water system. J. Power Sour. 219, 16-21 (2012)

18. Goldberg, S., Davis, J.A., Hem, J.D.: In: Sposito, G. (ed.) The Environment Chemistry of Aluminum, chap. 7, pp. 271-331. Lewis, London (1996) 